\title{
FISH DIGENEANS FROM THE SEVEN ISLANDS ORNITHOLOGICAL RESERVE AT OŚWIN LAKE POLAND. PART I. POSTHODIPLOSTOMUM CUTICOLA VON NORDMANN, 1832
}

\author{
Katarzyna MIERZEJEWSKA ${ }^{1 *}$, Teresa WŁASOW ${ }^{2}$, \\ Anita KAPUSTA ${ }^{2}$, Krzysztof SZYMAŃCZYK ${ }^{3}$
}

\author{
${ }^{1}$ Division of Fish Biology and Pisciculture \\ ${ }^{2}$ Division of Evolutionary Genetics, University of Warmia and Mazury in Olsztyn, Poland \\ 3 Provincial Office of the Department of Environmental Protection in Olsztyn, Poland
}

Mierzejewska K., Własow T., Kapusta A., Szymańczyk K., 2004. Fish digeneans from the Seven Islands ornithological reserve at Oświn Lake, Poland. Part I. Posthodiplostomum cuticola von Nordmann, 1832. Acta Ichthyol. Piscat. 34 (1): 73-84.

Background. The study was carried out in the shallow, eutrophic Oświn Lake, in the area of the Seven Islands ornithological reserve (north-eastern Poland) to determine the infection of fish with digeneans maturing in piscivorous birds. This paper presents a comparative analysis of the occurrence of Posthodiplostomum cuticola in fishes from two parts of the reservoir differing in environmental conditions. The effect of fish size and season of sampling on the infection level was analysed.

Material and methods. Within 1998 and 1999, a total of 1091 fishes of 8 species dominating in the lake were examined. Samples were collected four times a year (in May, July, August, and October) simultaneously from the two examined parts of the lake.

Results. Metacercariae of $P$. cuticola occurred with high prevalence and intensity of infection in roach, rudd, white bream, and carp bream, and sporadically in crucian carp and European perch. The intensity of infection of fish from the western part of the lake was significantly higher compared with the eastern part; roach from the western pool were much more infected than in the other reservoirs of north Poland. The infection of roach, white bream and carp bream increased with total body length (TL), such a relationship was not reported for rudd. The infection of roach, white bream and carp bream varied significantly in different experimental periods while differences in the infection of rudd in samples were incidental.

Conclusion. Location-dependent occurrence of $P$. cuticola in fishes indicates that interchange between fish groups from the eastern and western pool of Oświn Lake is

\footnotetext{
* Correspondence: Dr Katarzyna Mierzejewska, Katedra Biologii i Hodowli Ryb, Uniwersytet Warmińsko-Mazurski w Olsztynie, ul. Oczapowskiego 5, 10-957 Olsztyn, Poland. Phone/ fax: (+48-89) 523-3290,

e-mail: katarzyna.mierzejewska@uwm.edu.pl
} 
Mierzejewska et al.

limited. Infection of rudd was of a more incidental character then the infection of roach, white bream, and carp bream.

Key words: parasite, fish, Posthodiplostomum cuticola, Oświn Lake, Seven Islands reserve, Poland.

\section{INTRODUCTION}

Metacercariae of Posthodiplostomum cuticola von Nordmann, 1832 parasitise cyprinids (Cyprinidae), percids (Percidae), pikes (Esocidae), salmonids (Salmonidae), and others (Bauer 1987) causing the formation of characteristic cysts, with a strong melanization. The intensive infections are referred to as the black spot disease.

Snails Planorbis planorbis and $P$. carinatus serve as a first intermediate host of $P$. cuticola. Piscivorous birds of Ardeidae, usually common heron (Ardea cinerea), purple heron (A. purpurea), Squacco heron (Ardeola ralloides), and night heron (Nycticorax nycticorax) (cf. Jara and Chodyniecki 1999) are the final host. In the 1950s, the abundance of $P$. cuticola metacercariae was attributed to the presence of common heron colonies in the area of Oświn Lake (north-eastern Poland) (Kozicka 1963). At present, no breeding sites of heron are located in the Seven Islands reserve covering Oświn Lake (Sikora et al. unpublished). The closest colony is located $4.5 \mathrm{~km}$ to the south, at Rydzówka Lake (Mirowska-Ibron, personal communication). In the 1970s, after a rapid draw down, Oświn Lake underwent accelerated eutrophication. In 1983, intoxication with chemical fertilizers caused mass fish kills. Since that time, the reserve has been protected by the Ramsar Convention (The List of Wetlands of International Importance). At present, 122 species of birds are nesting in this area (Sikora et al. unpublished).

The water level increasing in 1993 prompted by the dam construction on the Oświnka River, caused a recession of the eutrophication process. At present, pond type Oświn Lake (surface area: 890 ha; mean depth: $1.7 \mathrm{~m}$ ) is a reservoir of a moderately advanced eutrophication (Wróbel and Królikowska 1999, Królikowska and Wróbel unpublished, Wiśniewski unpublished). There are two large basins: eastern and western in the lake separated by a shallow (Fig. 1).

The western part is more overgrown by trees and bushes then the eastern one. The bottom of the eastern basin contrary to the western one is completely covered with hornwort (Ceratophyllum demersum). The current microbiological analysis of water indicated that the eastern part of Oświn Lake is more fertile (Własow et al. 2003).

Differences in the occurrence of black spot disease in particular parts of the lake were observed during catches (controlled by protection regulations). Locationdependent infection with $P$. cuticola was not investigated prior to the ecological catastrophe (Kozicka 1963, Grabda and Grabda unpublished). Therefore, it was reasonable to study the current rate of fish infection with $P$. cuticola in both parts of Oświn Lake. The effect of fish size and sample collection period on the infection level was also analysed. 


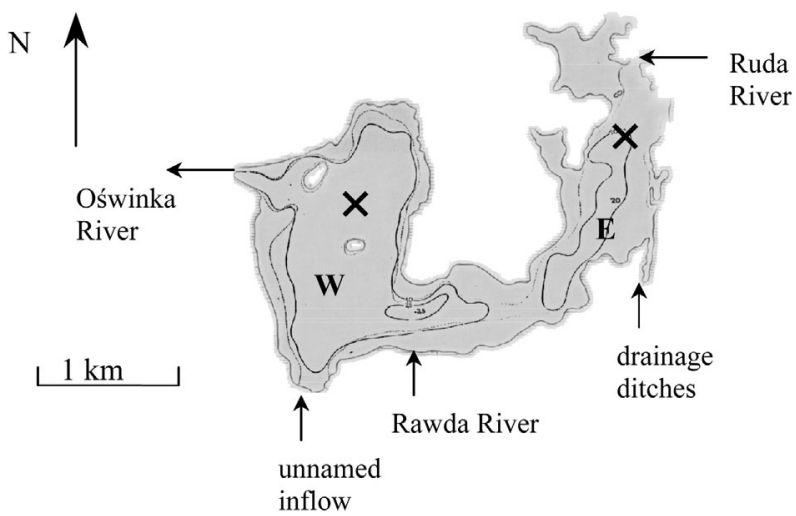

Fig. 1. Location of sampling areas of fish $(\mathbf{X})$ in Oświn Lake; E, eastern-; W, western part of the lake

\section{MATERIAL AND METHODS}

Throughout 2 years (1998 and 1999), a total of 1091 fishes belonging to 8 dominant species were examined: northern pike (Esox lucius), roach (Rutilus rutilus), rudd (Scardinius erythrophthalmus), tench (Tinca tinca), white bream (Blicca bjoerkna), carp bream (Abramis brama), crucian carp (Carassius carassius), and European perch (Perca fluviatilis).

The fishes were caught with nets (mesh $30 \times 30 \mathrm{~mm}$ ) in the eastern and western basins four times per year (in May, July, August, and October) (Table 1). Specimens examined had a broad range in length (Table 2).

Table 1

Number of fish in samples from the eastern- (E) and western (W) part of Oświn Lake

\begin{tabular}{|c|c|c|c|c|c|c|c|c|}
\hline \multirow{3}{*}{$\begin{array}{c}\text { Fish } \\
\text { species }\end{array}$} & \multicolumn{8}{|c|}{ Samples } \\
\hline & May 98 & Jul 98 & Aug 98 & Oct 98 & May 99 & Jul 99 & Aug 99 & Oct 99 \\
\hline & \multicolumn{8}{|c|}{ No. E / No. W } \\
\hline $\begin{array}{l}\text { Northern } \\
\text { pike }\end{array}$ & $10 / 5$ & $3 / 3$ & $6 / 10$ & $10 / 11$ & $7 / 10$ & $10 / 4$ & $10 / 10$ & $6 / 10$ \\
\hline Roach & $15 / 15$ & $5 / 10$ & $2 / 7$ & $10 / 9$ & $7 / 8$ & $9 / 10$ & $10 / 10$ & $7 / 10$ \\
\hline Rudd & $14 / 9$ & $10 / 6$ & $9 / 3$ & $8 / 5$ & $10 / 10$ & $10 / 8$ & $10 / 10$ & $8 / 6$ \\
\hline Tench & $3 / 1$ & $8 / 1$ & $10 / 5$ & $10 / 10$ & $10 / 10$ & $10 / 10$ & $10 / 10$ & $6 / 9$ \\
\hline $\begin{array}{l}\text { White } \\
\text { bream }\end{array}$ & $15 / 13$ & $7 / 10$ & $0 / 5$ & $0 / 10$ & $10 / 10$ & $10 / 2$ & $10 / 10$ & $7 / 10$ \\
\hline $\begin{array}{l}\text { Carp } \\
\text { bream }\end{array}$ & $14 / 14$ & $10 / 10$ & $10 / 10$ & $10 / 8$ & $10 / 10$ & $10 / 10$ & $10 / 10$ & $7 / 10$ \\
\hline $\begin{array}{l}\text { Crucian } \\
\text { carp }\end{array}$ & $3 / 0$ & $10 / 5$ & $10 / 2$ & $6 / 0$ & $7 / 6$ & $10 / 9$ & $10 / 10$ & $10 / 8$ \\
\hline $\begin{array}{l}\text { European } \\
\text { perch }\end{array}$ & $13 / 15$ & $10 / 10$ & $10 / 10$ & $9 / 11$ & $7 / 10$ & $10 / 10$ & $10 / 10$ & $10 / 10$ \\
\hline
\end{tabular}


Table 2

Comparison of the total body length (TL) of fish sampled in the eastern (E) and western $(\mathrm{W})$ part of Oświn Lake. $U$, Mann-Whitney statistics

\begin{tabular}{lcccc}
\hline \multicolumn{1}{c}{ Fish species } & TL $[\mathrm{cm}]-\mathrm{E}$ & $\mathrm{TL}[\mathrm{cm}]-\mathrm{W}$ & \multirow{2}{*}{$\bar{x} \pm s($ range $)$} & $P$ \\
\hline Northern pike & $58.03 \pm 12.35(33.0-97.0)$ & $56.99 \pm 12.74(33.0-77.0)$ & 1932.5 & $>0.05$ \\
Roach & $19.48 \pm 4.31(14.0-31.0)$ & $21.02 \pm 4.82(14.5-36.0)$ & 2076.0 & $<0.05$ \\
Rudd & $22.64 \pm 4.83(13.5-32.0)$ & $24.24 \pm 4.07(14.5-31.0)$ & 1816.0 & $>0.05$ \\
Tench & $34.65 \pm 4.94(27.0-47.5)$ & $33.57 \pm 3.40(27.5-40.0)$ & 1695.5 & $>0.05$ \\
White bream & $18.29 \pm 4.08(13.0-27.5)$ & $19.24 \pm 4.07(12.0-27.0)$ & 1762.5 & $>0.05$ \\
Carp bream & $29.52 \pm 4.03(23.0-41.0)$ & $27.62 \pm 5.28(12.0-42.0)$ & 2581.5 & $<0.05$ \\
Crucian carp & $24.40 \pm 5.48(14.0-48.0)$ & $26.50 \pm 5.33(11.0-35.0)$ & 938.5 & $<0.05$ \\
European perch & $22.53 \pm 6.42(13.0-41.0)$ & $22.67 \pm 4.94(13.5-35.0)$ & 2936.5 & $>0.05$ \\
\hline
\end{tabular}

The prevalence and intensity of infection (mean value and range) were calculated following Margolis et al. (1982). Non-parametric statistics were used to find differences in the infection of fish with $P$. cuticola: the Kruskal-Wallis $H$-test to compare the different sampling periods and the Mann-Whitney $U$-test to compare sampling sites. Differences in the total body length of fish examined in particular parts of the lake were estimated by $U$-test. To find the fish size and intensity of infection relationship the Pearson's correlation coefficient was calculated.

\section{RESULTS}

Cysts with metacercariae of Posthodiplostomum cuticola were observed in the skin, subcutaneous tissue, fins, and on the outer and inner side of the operculum and on the scales, gill arches and the mouth cavity of the most extensively infected fishes. The parasite numerously occurred in roach, rudd, white bream and carp bream; with intensity of infection up to $392,282,210$, and 119 parasites per fish, respectively (Table 3). Crucian carp and European perch were sporadically infected (Table 3). 
Table 3

Comparison of the fish infection with Posthodiplostomum cuticola in the eastern (E) and western (W) part of Oświn Lake

\begin{tabular}{cccc}
\hline \multirow{2}{*}{ Fish } & Prevalence [\%] & \multicolumn{2}{c}{ Intensity of infection } \\
\cline { 3 - 4 } & E / W & Mean E / W & Range E / W \\
\hline Northern pike & $0 / 0$ & $0 / 0$ & $0 / 0$ \\
Roach & $63.1 / 81.0$ & $9.3 / 60.3$ & $1-56 / 1-392$ \\
Rudd & $39.2 / 54.5$ & $5.4 / 28.2$ & $1-42 / 1-282$ \\
Tench & $0 / 0$ & $0 / 0$ & $0 / 0$ \\
White bream & $71.2 / 87.1$ & $25.9 / 28.1$ & $1-210 / 1-180$ \\
Carp bream & $32.1 / 52.4$ & $4.9 / 11.8$ & $1-17 / 1-119$ \\
Crucian carp & $0 / 2.5$ & $0 / 1.0$ & $0 / 1$ \\
European perch & $1.3 / 0$ & $3.0 / 0$ & $3 / 0$ \\
\hline
\end{tabular}

Prevalence in roach varied from 0 to $80 \%$ in samples from the eastern basin and from 70 to $100 \%$ in samples from the western one. In rudd it ranged from 0 to $62.5 \%$ and from 20 to $83.3 \%$, respectively; in carp bream-from 0 to $60 \%$ and from 14.3 to $87.5 \%$, respectively; in white bream-from 40 to $100 \%$ in both pools (Fig. 2).
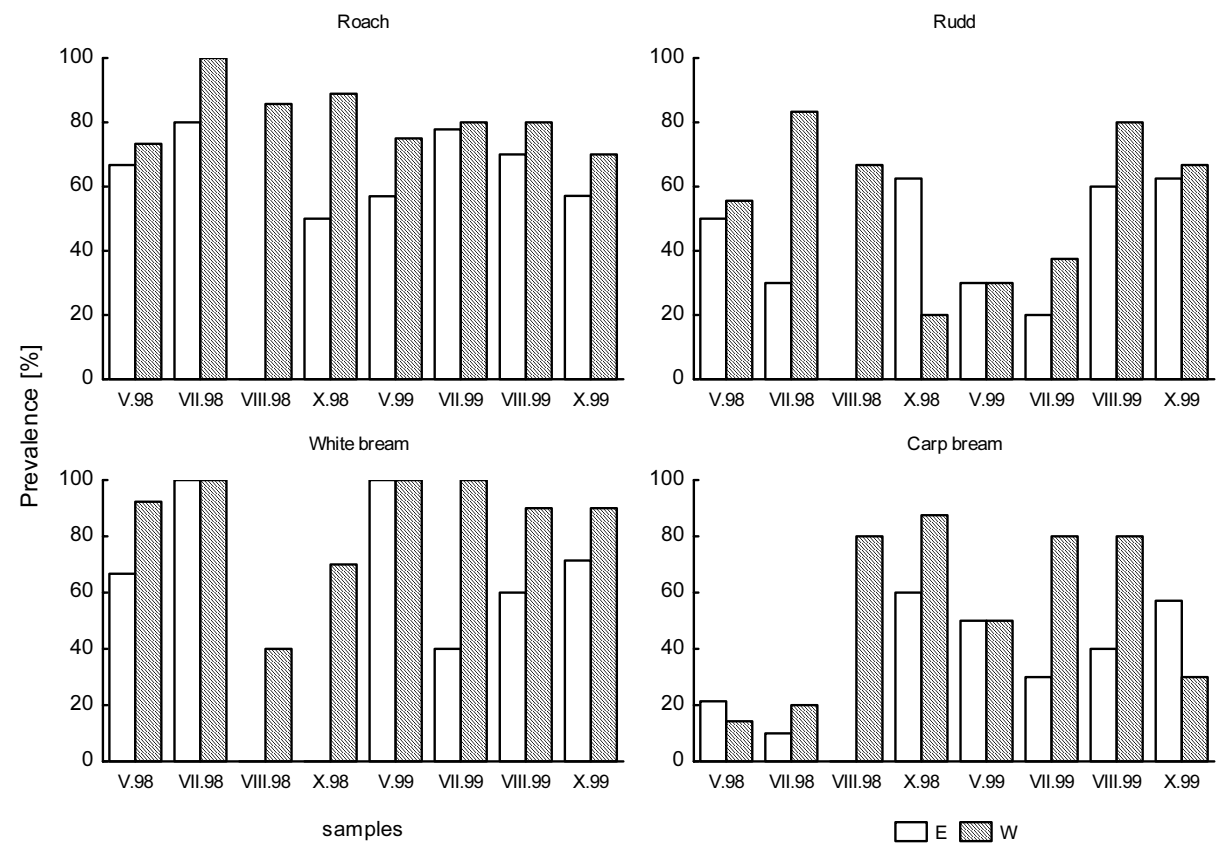

Fig. 2. Prevalence of P. cuticola in fish from eastern (E) and western (W) part of Oświn Lake 
Intensity of infection in roach peaked in July 1998 in both pools (mean value 167.5 parasites per fish in the western part, and 19.2 in the eastern one) (Fig. 3). In rudd it peaked in May 1998 (82.2) and in October 1999 (11.2), respectively (Fig. 4). In white bream the intensity of infection increased in July 1998 in both basins and reached on an average 65.6 in the western- and 58.1 in the eastern pool (Fig. 5). In carp bream it peaked in August 1998 (24.1) and in May 1998 (10), respectively (Fig. 6).

In accordance with the $H$-test result the infection of roach, white bream and carp bream differed significantly in sampling periods (Figs. 3, 5, 6), the infection of rudd was not time-dependent (Fig. 4). The infection level of roach, rudd, white bream, and carp bream was visibly higher in the western part of the lake than in the eastern part (Table 3). Location dependent differences were find by $U$-test in all mentioned-above fishes (Figs. 3, 4, 5, 6). Number of parasites increased with increasing the total body length (TL) of roach, white bream, and carp bream (Fig. 7). Such a correlation did not occur in the case of rudd $(P>0.05)$.

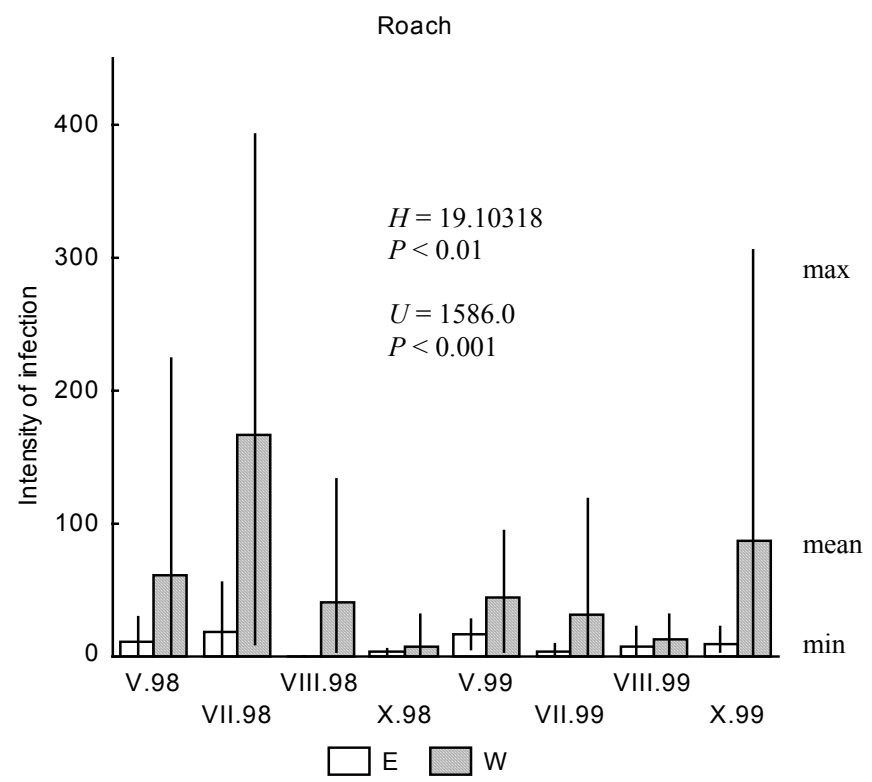

Fig. 3. Intensity of infection of roach with $P$. cuticola in samples from eastern- (E) and western (W) part of Oświn Lake; $H$, Kruskal-Wallis statistic for seasonal differences; $U$, Mann-Whitney statistic for location differences 


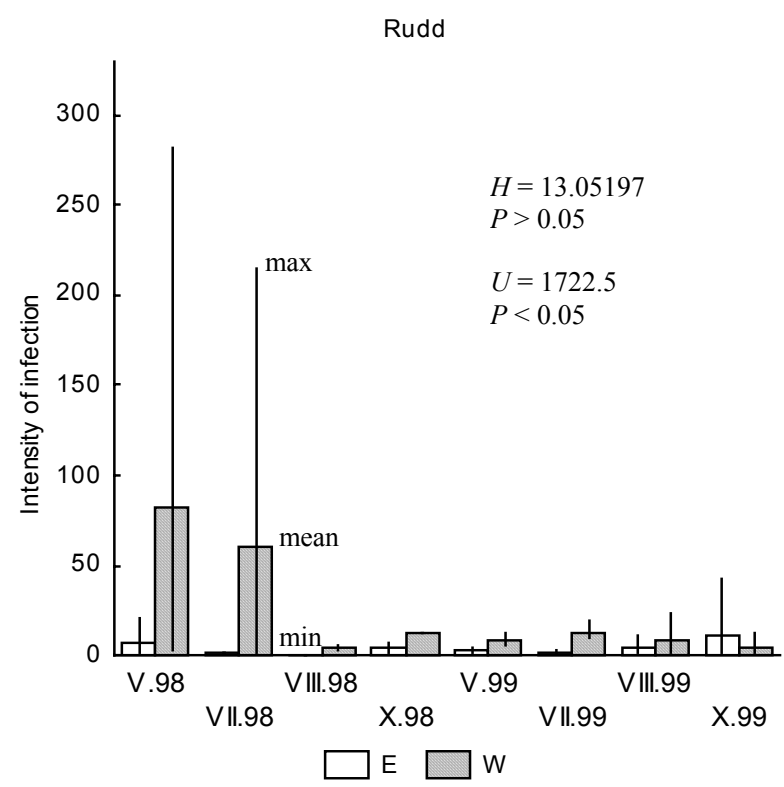

Fig. 4. Intensity of infection of rudd with $P$. cuticola in samples from eastern- (E) and western (W) part of Oświn Lake; $H$, Kruskal-Wallis statistic for seasonal differences; $U$, Mann-Whitney statistic for location differences

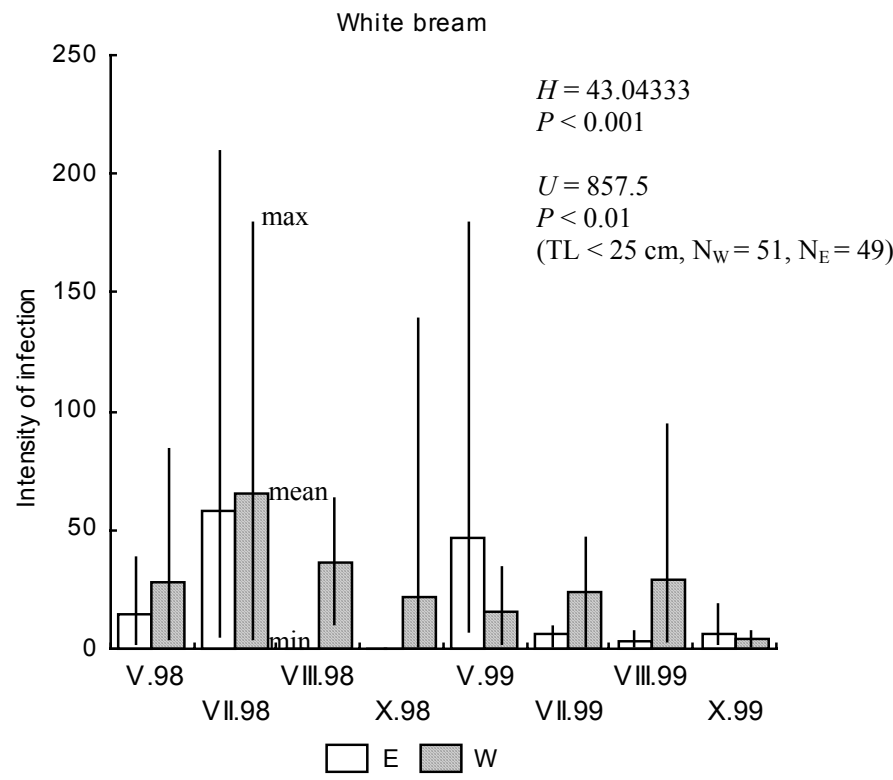

Fig. 5. Intensity of infection of white bream with $P$. cuticola in samples from eastern- (E) and western (W) part of Oświn Lake. $H$, Kruskal-Wallis statistic for seasonal differences. $U$, Mann-Whitney statistic for location differences 


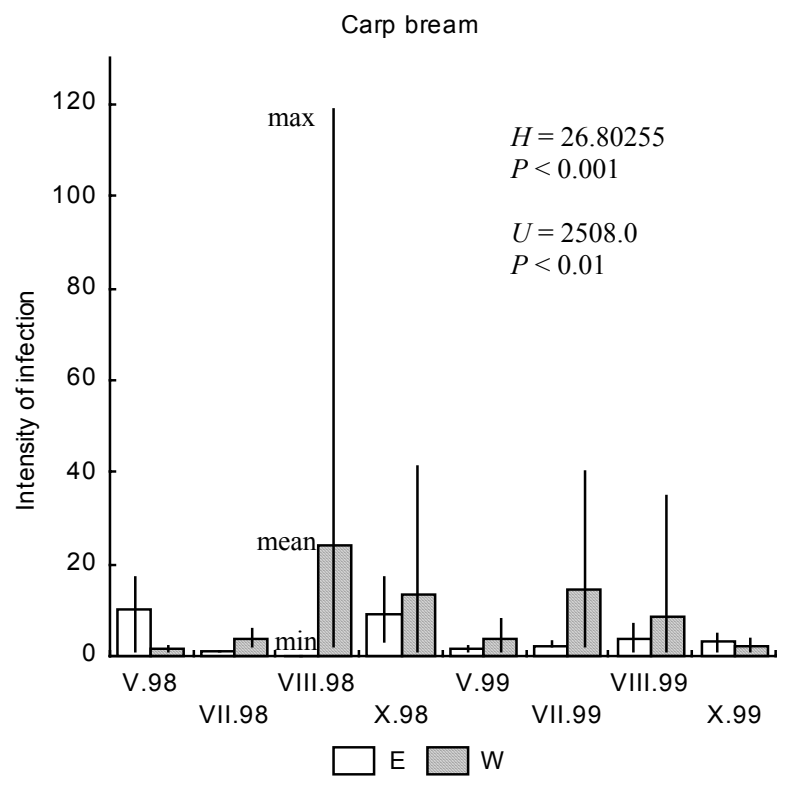

Fig. 6. Intensity of infection of carp bream with $P$. cuticola in samples from eastern- (E) and western (W) part of Oświn Lake; $H$, Kruskal-Wallis statistics for seasonal differences; $U$, Mann-Whitney statistic for location differences

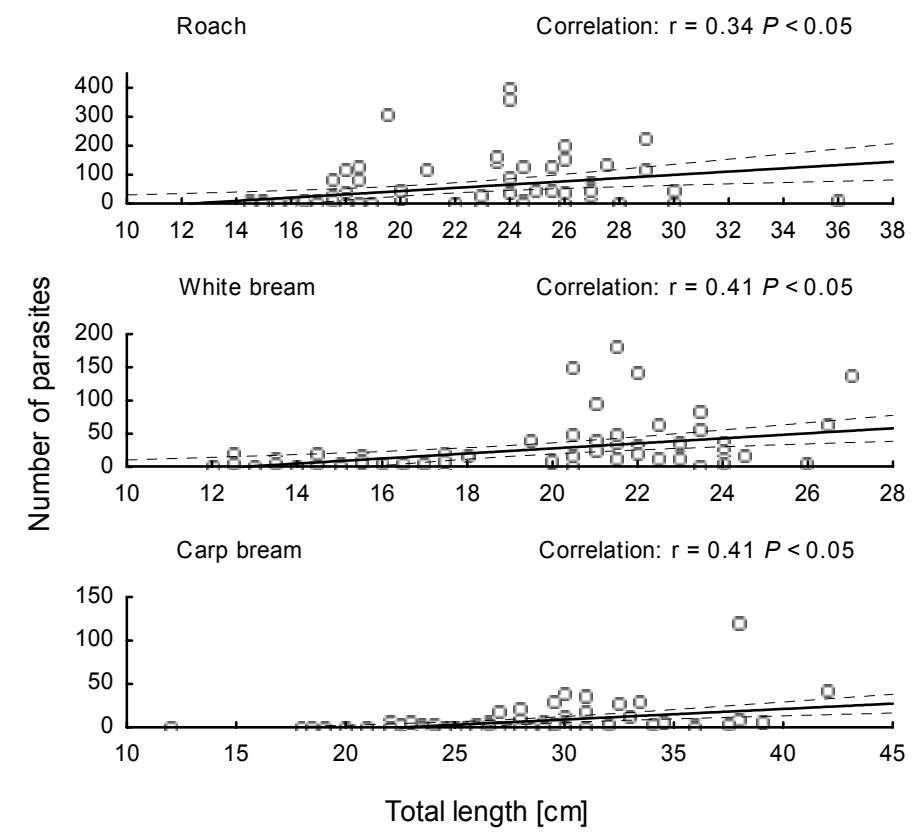

Fig. 7. Relationship between the number of $P$. cuticola and the total length (TL) of fish from western part of Oświn Lake 
Thus, differences in body length of rudd examined in particular sites (Table 2) could not influence the location dependent differences. The total body length of white bream examined varied between the pools (Table 2) so, to find differences in the infection of fish, the groups of uniform length were chosen $\left(\mathrm{TL}<25 \mathrm{~cm} ; \mathrm{N}_{\text {west }}=51\right.$, $\left.\mathrm{N}_{\text {east }}=49\right)$ (Fig. 5).

\section{DISCUSSION}

Compared to the other reservoirs of northern Poland, the abundance of Posthodiplostomum cuticola in fish from Oświn Lake was exceptionally high, even in the 1950s (Kozicka 1963, Grabda and Grabda unpublished). Upon the activity of selective factors connected with ecological catastrophe (accelerated eutrophication, intoxication with chemical fertilizers, the mass fish kills in 1983), and then, upon the increase in water level in 1993-P. cuticola remains a characteristic component of piscine parasite fauna in the lake studied (Table 3). In the 1950s, the high infection level of roach, rudd and white bream was attributed to the size of the common heron colony at Oświn Lake (Kozicka 1963). At present, the main source of P. cuticola infective stages are probably beards migrating from the nearest colony because there are no breading herons in the Seven Islands reserve covering Oświn Lake (Sikora at al. unpublished).

An analysis of samples from the eastern and western part of Oświn Lake indicated considerable differences in the occurrence of $P$. cuticola in the fish examined. This parasite was more abundant in the western part, with considerably higher infection of all important hosts (Table 2, Figs. 3-6). A clear difference was found in the maximum intensity of infection; in the eastern part—up to 56 cysts per fish occurred in roach, up to 42 in rudd, and up to 17 in carp bream, whereas in fish of the western part, the values reached up to 392,282 , and 119 , respectively (Table 3 ). In most samples, the intensity of infection was higher in the western basin then in the eastern one (Figs. 3-6), but prevalence was usually high and uniform in both (Fig. 2).

In the eastern part of Oświn Lake, the infection of fish with $P$. cuticola was comparable to that reported in other lakes of northern Poland, e.g. in Drużno Lake (Kozicka 1958), in Tajty Lake (Kozicka 1953), in Dgał Wielki and Warniak lakes (Grabda-Kazubska et al. 1987), but in the western part it was usually higher.

In order to explain the different occurrence of parasite within the same water body, it should be mentioned that the presence of a parasite is, to a high extent, determined by the status of the final host in a given area (Xianghua 1987) and by the availability of intermediate hosts as well (Køie 1988, Moser and Cowen 1991).

The occurrence of Digenea may be limited by the distribution of snails- the intermediate hosts. Often, despite a high number of birds (the definitive host), common digenetic fish parasites are not observed in a given area. The restrictive effect of molluscs on digeneans has been observed in the Gulf of Gdańsk and the Vistula Lagoon (Rolbiecki et al. 1999), in the Gulf of Bothnia (Valtonen et al. 2001), 
Kis-Balaton (Székely and Molnár 1996/1997) and in polluted Vatia Lake (central Finland) (Valtonen et al. 1997).

One cannot exclude that the different physicochemical conditions of water and sediments in the investigated basins of Oświn Lake (Wiśniewski unpublished) induced differences in the distribution of planorbid snails in the reservoir, and thus create differences in fish infection with $P$. cuticola. Lack of data referring to molluscs of Oświn Lake makes verification of this assumption impossible.

The western pool is more overgrown by bushes and tress than the eastern part, this may enhance development of allogenic parasites (Niewiadomska et al. 2001). On the other hand, the bottom of the eastern basin is strongly covered with Ceratophyllum demersum; it may discourage birds from hunting in this area, and affect a decrease of fish infection with $P$. cuticola. It may be well to add that the Rawda River, which provides Oświn Lake with water from Rydzówka Lake (inhabited by herons) falls into the western pool. (Is it infected?)

The results of this study indicated that there are some groups of roach, rudd, white bream, and carp bream staying for a longer period in the particular parts of Oświn Lake. The parasitological investigations of Balling and Pfeiffer (1997) confirmed that the interchange between perch and roach populations in Lake Constance is limited. Also Wierzbicki (1971) noted such isolation of perch groups in Dargin Lake.

P. cuticola causes pathological changes in the internal organs of host, which may lead to the death of young fish, especially. At a high intensity of infection, disturbance in the metabolism of fatty compounds occurs, and the body weight of infected fish decreases (Afanasjev 1978). Chybowski et al. (unpublished) did not find any limitation in fish grow rate in Oświn Lake.

The infection of roach, white bream and carp bream was positively correlated with total body length (TL) (Fig. 7). It demonstrates the acquisition of parasites with age (Croll 1977). Such a relationship was not observed in rudd $(P<0.05)$, thus, the infection of that fish is more incidental. The infection of rudd with $P$. cuticola did not depend on the sampling period, whereas infection of roach, white bream and carp bream differed significantly in seasons. However, no cyclic changes in parasite abundance, which occurs simultaneously in both pools and in all hosts, were observed (Figs. 2-6). Thus, there is no evidence for seasonal changes in the occurrence of $P$. cuticola in the fish examined.

\section{SUMMARY}

1) Posthodiplostomum cuticola occurred commonly and in high abundance in fishes of Oświn Lake and, upon the activity of selective factors, remains a characteristic component of fish parasite community.

2) The intensity of fish infection with P. cuticola in the western part of Oświn Lake was significantly higher then in the eastern part. Location-dependent occurrence of the parasite indicates that interchange between fish groups from the western and eastern pool of the lake is limited. 
3) The infection rate of roach, white bream, and carp bream increased with an increasing of fish total body length as a result of parasite acquisition with age. The infection of rudd was of a more incidental character.

4) The changes in fish infection with $P$. cuticola in different samples were not of a seasonal character.

\section{ACKNOWLEDGMENTS}

This study was supported by research grant (number 080302.0205) from the University of Warmia and Mazury in Olsztyn.

\section{REFERENCES}

Afanasjev V.I., 1978. Osobennosti patogeneza pri lerneoze, arguloze i postodiplostomoze. [Peculiarities of pathogenesis related to lerneosis, argulosis, and posthodiplostomosis.] Veterinaria, Moskva 8: 71-72. (In Russian.)

Balling T.E., Pfeiffer W., 1997. Location-dependent infection of fish parasites in Lake Constance. Journal of Fish Biology 51: 1025-1032.

Bauer O.N., (ed.) 1987. Opredelitel' parazitov presnovodnyh ryb SSSR. Tom 3. Parasitičeskie mnogokletočnye (Vtoraâ cast'). [Key to the parasites of freshwater fishes of the USSR. Vol. 3. Parasitic metazoans (Part two).] Izdatel'stvo Nauka, Leningrad. (In Russian.)

Croll N.A. 1977. Pasożytnictwo i inne związki. [Parasitism and other relationships.] PWN, Warszawa. (In Polish.)

Grabda-Kazubska B., Baturo-Warszawska B., Pojmańska T., 1987. Dynamics of parasite infestation of fish in lake Dgał Wielki and Warniak in connection with introduction of phytophagous species. Acta Parasitologica Polonica 32 (1): 1-28.

Jara Z., Chodyniecki A., 1999. Ichtiopatologia. [Fish pathology.] Wydawnictwo Akademii Rolniczej we Wrocławiu, Wrocław. (In Polish.)

Kozicka J., 1953. Pasożyty ryb w jeziorze Tajty. [Parasites of fish in Tajty Lake.] Roczniki Nauk Rolniczych D 67: 171-186.

Kozicka J., 1958. Diseases of fishes of Drużno Lake. Parasitofauna of the biocenosis of Drużno Lake—Part VII. Acta Parasitologica Polonica 6 (20): 393-432.

Kozicka J., 1963. Attempt of fishery-parasitologic estimation of the lakes of Węgorzewo establishment. Acta Parasitologica Polonica 11 (8): 113-13.

Køie M., 1988 Parasites in eels, Anguilla anguilla (L.) from eutrophic Lake Esrum (Denmark). Acta Parasitologica Polonica 33 (2): 89-100.

Margolis L., Esch G.W., Holmes J.C., Kuris A.M., Schad G.A., 1982. The use of ecological terms in parasitology (report of an ad hoc committee of the American Society of Parasitologists). International Journal for Parasitology 68: 131-133.

Moser M., Cowen R.K., 1991. The effect of periodic eutrophication on parasitism and stock identification of Trematomus bernacchii (Pisces: Nototheniidae) in McMurdo Sound, Antarctica. Journal of Parasitology 77 (4): 551-556.

Niewiadomska K., Pojmańska T., Machnicka B., Czubaj A., 2001. Zarys parazytologii ogólnej. [An outline of general parasitology.] PWN, Warszawa. (In Polish.) 
Rolbiecki L., Rokicki J., Morozińska-Gogol J., Chibani M., 1999. Larval stages of helminths in fish from the Vistula Lagoon and the Gulf of Gdańsk in relation to bird occurrence. Bulletin of Sea Fish Institute 2 (147): 51-60.

Székely C., Molnar K., 1996/97. Preliminary survey of the parasite fauna of some important fish species in the Upper-Reservoir of the Kis-Balaton System. Parasitologica Hungarica 29-30: 45-54.

Valtonen E.T., Holmes J.C., Koskivaara M., 1997. Eutrophication, pollution and fragmentation: effects on parasite communities in roach (Rutilus rutilus) and perch (Perca fluviatilis) in four lakes in Central Finland. Canadian Journal Aquatic Fisheries Sciences 54: 572-585.

Valtonen E.T., Pulkkinen K., Poulin R., Julkunen M., 2001. The structure of parasite component communities in brackish water fishes of the north-eastern Baltic Sea. Parasitology 112: 471-481.

Wierzbicki K., 1971. The effect of ecological conditions on the parasite fauna of perch Perca fluviatilis L. in Lake Dargin. Ekologia Polska 19: 73-86.

Własow T., Zmysłowska I., Lewandowska D., Mierzejewska K., Idzikowski R., Ziomek E., 2003. Bacteria and parasites on the gills of pike Esox lucius L. and tench Tinca tinca (L.) as indices of the trophic level of Oświn Lake (northeastern Poland). Archives of Polish Fisheries. 11, 2: 225-235.

Wróbel J., Królikowska J., 1999. Problemy ochrony ekosystemów wodnych i torfowiskowych w polskich parkach narodowych. [The problems of active protection of water- and peat ecosystems in Polish national parks.] Wydawnictwo Uniwersytetu Marii Curie-Skłodowskiej w Lublinie, Lublin.

Xianghua L., 1987. Factors regulating trematodes and cestodes in fish. Archiv für Hydrobiologie; Ergebnisse der Limnologie 28: 381-387.

Received: 5 February 2004

Accepted: 21 June 2004 